\title{
Regulation and Law Enforcement Aspects of Maritime Security
}

\author{
Ambar Suwardi ${ }^{1}$, Zudan Arief Fakhrulloh ${ }^{2}$ \\ \{ambar.suwardi70@yahoo.com ${ }^{1}$, cclsis@yahoo.com² ${ }^{2}$ \} \\ Universitas Borobudur, Jakarta, Indonesia ${ }^{1,2}$
}

\begin{abstract}
Indonesia is classified as an archipelagic state and a maritime country due to its geographical location and natural resource potential. This also makes Indonesia the global supply chain system's center of gravity. As a result of the situation, Indonesians are subjected to threats, intimidation, and restrictions, which has ramifications for the country's marine security. This position requires a robust security and defense structure, as well as changing patterns of national growth that are not only focused on the land but also on the sea. Because numerous policies and laws have been formed, but these regulations are still sectoral, resulting in confusion and overlapping norms and authority in marine security. This holds true for the law enforcement system and state sovereignty at sea, both of which are impacted by the Act. On this foundation, the regulatory aspects of maritime security and law enforcement must be carried out through harmonization of legal systems and legislation, prompt resolution and determination of state borders on land, sea, and air, and a focus on the Navy as the most responsible for maritime security and a leading sector.
\end{abstract}

Keywords: enforcement; law; maritime; security

\section{Introduction}

\subsection{Background}

Indonesia as a maritime country has famous since the Majapahit Kingdom and Srivijaya Kingdom. Apart from the two great kingdoms that, Indonesia also has a history maritime in the heyday of Koninklijke Paketvaart Maatschappij (KPM, 1888-1960), had world's largest cobatage fleet, fleet ocean Jakarta Lloyd who is present in various world ports. The sea for Indonesia is a geostrategic center that might unite and also has the potential to be a source of conflict between regions/countries. Indonesia has $80 \%$ of the area is in the form of sea, the area of which is reach $5,800,000 \mathrm{~km} 2$ with coastline $80,791 \mathrm{~km}$ long, and 17,504 islands that are one connected to each other by the sea. Other than that, Indonesia geographically has a very strategic between crossing two oceans with two continents, so that the Indonesian sea area become a sea lane that is very important for the world trade and cross shipping national and international. It means Indonesia functions as a global supply chain system with that geographic position. This position also puts Indonesia in a position and an important role in the relationship with the international world as the center of gravity for the Asia Pacific 
region. The strategic position with 10 neighboring countries, namely India, Thailand, Malaysia, Singapore, Vietnam, Philippines, Palau, Papua New Guinea, Timor Leste and Australia, with 11 provinces located in sea border area, namely Nanggroe Province Aceh Darussalam, North Sumatra Province, Riau Province, Riau Islands Province, Province North Kalimantan, North Sulawesi Province, Maluku Province, North Maluku Province, Province, East Nusa Tenggara, Papua Province, and West Papua Province. Indonesia's position in the position has four of the nine sea the world's lines of communication which resulted in Indonesia has a very big obligation ensure the safety and security of shipping in the Straits of Malacca, the South China Sea, and the three Indonesian archipelagic sea lanes. Position This has two meanings, namely first, to be in two cultural currents driven by market power and the power of primordial identity who are fighting in the midst of globalization and second, from the defense aspect, Indonesia is in the between maritime defense systems in the south and continental defense system in the north (Kartika, 2014).

Indonesia also has resources extraordinary sea, both from the marine aspect, aspects of fisheries, as well as technological innovation marine based. Beautiful nature background, makes the nation and Indonesia has a maritime pattern. Wealth Indonesian sea can contribute revenue of US\$ 1.2 trillion if calculated and processed optimally.All these potentials are recognized by the government have not made a maximum contribution for the economy, because the state is negligent watch over the wealth of the sea and its weakness marine knowledge in the field of marine spatial planning so that it is used by neighboring countries (Sitompul \& Setyawati, 2010).

Based on Law No. 17 Year 2007 on the National Development Plan Long Term 20052025 (UU RPJPN), marine resources have not been utilized optimally for several reasons, including: others: (1) there is no maritime boundary arrangement; (2) there is a conflict in the use of space at sea; (3) there is no security guarantee and safety at sea; (4) the existence of autonomy the area causes there is no understanding the same for resource management sea; (5) there is limited ability human resources in managing resources sea power; and (6) there is no support research, science and technology marine. Not yet optimal development and Indonesian marine exploration due to by the safe development paradigm it runs still based on land resulting in a disparity interregional development in Indonesia. Therefore, Indonesia's maritime territory is threatened, from within and from outside due to lack of protection and security in maritime areas country.

This problem arises because poor maritime connectivity resulting in high logistics costs and the most expensive in the world and many parties who carry out activities in the maritime area Indonesia that violates the provisions regulations, both nationally as well as international.

\subsection{Formulation of the problem}

Indonesia as an archipelagic country and maritime countries have a strategic position in the global supply chain system and the center of gravity with resource potential abundant nature in the Indonesian sea. With In this position, Indonesia faces many actual and potential threats, both internal and external. This condition is not supported by facilities and infrastructure so as to result in Indonesia's jurisdiction area is prone to various violations and crimes at sea. This illustrates that the marine sector the country is geopolitically and geostrategically is an important element in the field of defense and security, but still faced a lot of problems. Government has made legal instruments for maintain national sovereignty and security maritime in the area of national jurisdiction, however Until now, Indonesia is still facing threats to maritime security in his territory. On that basis, the problem The laws that will be 
studied in this paper are: how are the arrangements regarding management and security of the country's maritime territory in laws and regulations and how to enforce maritime law in the related Indonesian marine waters with the country's maritime security.

\subsection{Purpose}

The study in this paper is intended to know the arrangements regarding management and safeguarding the maritime territory of the country in legislation and enforcement maritime law in marine waters Indonesia related to maritime security country. It is hoped that this study will add to knowledge of maritime security and is expected to be an input for the policy maker in implementing legislative and supervisory functions of maritime security and existing regulations.

\section{Framework}

\subsection{Law of the Sea and Maritime Security}

The state is a legal order, whose terms of establishment are determined by at least not three main elements, namely territorial, people, and state power or government. With regard to these main elements, The territory of a country includes land space, air, and sea. All things related with sea space is often referred to as maritime. Maritime is understood by many limited to shipping and industry supporters, which refers to three points, namely relating to adjacent to sea, relating to marine

shipping or navigation, and resembling a mariner (Kartika, 2014). These three points cannot be separated from the principle of the law of the sea, namely res nullius and res communis. According to Hasyim Djalal (Dar, 2010), there are the battle between the two principles of the law of the sea that, namely: a. The principle of res nullius says that the sea no one has it, because it can be owned by every country that want it; whereas b. The principle of res communis says that the sea common property of the world community, because it cannot be owned by every country.

These two principles of the law of the sea can be used in determining the territory of a country. Something the territory that has been confirmed as a territory State sovereignty has consequences the country is fully sovereign inhabit and manage the area (Hadiwijoyo, 2009). The sovereignty of this country is one of the essential provisions of the United Convention Nations on the law of the sea Year 1982 (United Nations Convention of the Law of the Sea/UNCLOS 1982). this convention accommodate the concept of an archipelagic state. The archipelagic countries according to this convention are: a country consisting entirely of one or more island groups and may covers other islands, while the what is meant by an archipelago means a group of islands including parts of islands, waters between groups of islands these, and other natural forms. That's how they relate to each other so closely that clusters of islands, waters and other natural forms are an intrinsic geographical and political entity, or have historically been considered as one unity (Kartika, 2014). Based on the provisions in Chapter II, Chapter III, and Chapter IV UNCLOS 1982, countries Coastal and archipelagic countries have sovereignty over inland waters, waters islands and territorial seas, waters is a strait, the air space above it, base the sea and the subsoil, including sources natural resources contained in it. Even though a coastal country and an archipelagic country have that sovereignty, the two countries This is limited by various obligations, including: another obligation to respect 
peaceful traffic and the right of archipelagic sea lane passage by sea territorial and archipelagic waters owned by foreign ships.

Ivan Shearer who stated that in order to carry out sovereignty required jurisdiction, namely state legal authority to make the laws and regulations governing legal relations carried out by people either a citizen or a foreign citizen and property in its territory and includes the state's authority to forcing legal subjects to obey regulation (law) (Sodik, 2011). This means understanding the state cannot be separated from the concept the basis of the state as a geographical unit with its sovereignty and jurisdiction. Indonesia regulates the territory of this country in Constitution of the Republic of Indonesia Indonesia in 1945 (UUD 1945), namely Article 25A Chapter IXA concerning Territory of the State which declares that the Unitary State of the Republic of Indonesia is an archipelagic country which is characterized by the archipelago with areas that are its boundaries and rights are determined by Constitution. The territory of this country is regulated further with Law No 43 of 2008 concerning the Territory of the State (UU State Territory). The sovereignty and territory of this country is necessary protected from all forms of threats, both from domestically and from abroad can occur in land space, air space, and sea room (Sodik, 2011). For that, it is necessary to have national defense and security against its sovereign territory, including through maritime security. Marine policy Indonesia is based on Pancasila, the 1945 Constitution, the 1982 UNCLOS which has ratified by Law No 17 of 1985 concerning the Ratification of United 1982 Nations Convention of the Law of the Sea (Law 17/1985), and Law No. 172007 on Development Plan National Long Term 2005-2025 (RPJPN 2005-2025).

\section{Result and Discussion}

\section{Maritime Safety Analysis From Regulatory Aspect And Law Enforcement}

The sea has an important meaning for the nation and the state of Indonesia, namely the sea as a means of unifying the territory of the Republic of Indonesia, the sea as a means of transportation and communication, sea as natural resources for development economy, the sea as a defense force and state security. This means that Indonesia have an interest in protecting and maintaining maritime security to create conditions Indonesian waters that are safe from threats violation of territory, safe from the dangers of navigation shipping, safe from exploitation and exploration illegal against natural resources that become Indonesia's marine potential and pollution environment, and safe from crime and violations of the law, whether originating from domestically and from abroad. It means Indonesia adheres to the principle of res nullius and the concept of non-traditional maritime security. Aim is directed to achieve the goal country as defined in constitution, which is to protect the whole nation Indonesia and the entire homeland of Indonesia, promote public welfare, educate the life of the nation, and participate in implementing world order. To make that happen, it's wrong an effort made through the formation of legal instruments, both in the form of institutions as well as legal products. This legal instrument must pay attention to aspects of law and rule making and law enforcement. Regulations on maritime security closely related to statutory regulations which regulates the sea and all activities related to the sea. This considering the marine aspect of Indonesia saves enormous potential that involves many stakeholders are given authority to the Indonesian sea and its regulation scattered in several laws and regulations. 
The law can categorized into two, namely, first, general laws, such as State Territory Law, Spatial Planning Law, UU Defense; and secondly, laws that entirely regulates the sea, such as the Water Law, EEZ Law, PWP3K Law; Fisheries Law, UU Cruise.

The laws that apply in the sea has given regulation and authority the law of each agency, however not well coordinated, overlapping overlapping arrangements, overlapping authority stakeholders, as well as overlapping aspects of institutional, because there are more than 14 ministries/agencies and local government authority in it. An example of that overlap occurs in the economic zone area exclusive. Based on national law which regulated in Article 14 paragraph (1) of the EEZ Law, the territory EEZ is the responsibility of the force Indonesian National Armed Forces (TNI-AL). In addition, Article 224 of UNCLOS 1982 explicitly does not directly determine that the agency the most authorized in the sea is the navy armed in a country. On that basis, TNI AL is responsible for all criminal acts and violations of law in marine waters Indonesia. However, at the implementation level there is a conflict of authority in this EEZ area between the Indonesian Navy and the Directorate General of Customs Excise when exercising the authority to carry out legal proceedings against ships that suspected of smuggling. Conflict too occurred between the TNI-AL and the Ministry of Marine and Fisheries patrolling at sea for inspection and investigation in Indonesia's EEZ when handling legal processes fishing boats that commit violations at sea. Conflict occurs due to lack of clarity regulation of the Directorate General's task area Customs and the Ministry of Maritime Affairs and Fishing, so it's not uncommon the interface between the TNI-AL and agencies others in handling cases of violations in Indonesian territorial waters, especially in the EEZ (Usadi, 2014). This example is one of the obstacles regulations for the development of maritime security, because existing regulations provide some strength of the authorized stakeholders and responsible for the marine area.

In order to law enforcement in Indonesian waters and jurisdiction of Indonesia, especially in carry out security and safety patrols in territorial waters and jurisdictions Indonesia formed the Maritime Security Agency (Bakamla) as stipulated in Article 59 paragraph (3) of the Marine Law. This Bakamla is non-ministerial government agency that domiciled and responsible directly to the President through coordination minister who coordinates it Institution. It has the task of conducting security patrols and safety in Indonesian waters and the jurisdiction of Indonesia, with perform function: a. formulate national policies in the field of security and safety in the region Indonesian waters and jurisdictions Indonesia; $b$. implement an early warning system security and safety in the region Indonesian waters and jurisdictions Indonesia; c. carry out maintenance, supervision, prevention and prosecution of violations law in the territorial waters of Indonesia and the jurisdiction of Indonesia; $d$. synergize and monitor the implementation water patrols by the relevant agencies; e. provide technical support and operations to related agencies; f. provide search assistance and aid in Indonesian waters and the jurisdiction of Indonesia; and g. perform other tasks in the system national defense (Usadi, 2014).

Enforcement of sovereignty and enforcement the law in this sea cannot be separated from Indonesia's maritime policy based on in the 2005-2025 RPJPN Law. Maritime security policy is carried out by guard, secure, defend,supervising and protecting territorial integrity sovereignty of the Republic of Indonesia and jurisdiction in the ZEEI and Indonesian Continental Shelf, including sources natural resources and marine environment, in order to create people's welfare. This security policy uses two strategies, namely forming the Indonesian Coast Guard strong and increase ability defense and security at sea. The first Strategy is done with two efforts, namely: 


\subsection{Accelerate the formation of Indonesian}

The Coast Guard who has the authority multi-function in maritime law enforcement, search and rescue at sea, environment protection, shipping safety, fishery protection, and custom and immigration, with institutions that responsible are the Navy, Police, Ministry of Transportation, Ministry of Finance, Ministry of Maritime Affairs and Fisheries, National SAR Agency, and State Ministry of Empowerment State Apparatus; and

3.2 Develop operations management system effective Indonesian Coast Guard and efficient, with responsible institutions The responsibility is TNI AL, POLRI, Ministry Transportation, Ministry of Finance, Ministry of Maritime Affairs and Fisheries, and National SAR Agency

Formation Bakamla is related to the mandate of the Act Cruise about the sea and coast guard. Besides that, internationally regarding security, safety, law enforcement, and enforcement sovereignty at sea has been determined in several international conventions, namely the Convention International on the Safety of Life at Sea (International Convention for Safety of Life at Sea/SOLAS 1974) regarding state obligations signatories to form an organization coast guard or bodyguard sea and coast (sea and coast guard), Provisions International on Ship Safety and Port Facilities 2002 (International Ships and Port Facilities Security Code 2002/ ISPS Code 2002) regarding state obligations participants to establish national authorities and local authorities responsible for maritime safety and security, UNCLOS 1982 concerning the enforcement of the law of the sea by flag state, by country port (port state), and by the coastal state (coastal state) as regulated in Article 217, Article 218, and Article 220 of UNCLOS.

\section{Closing}

\subsection{Conclusion}

Geographical, geopolitical, and position and potential oceanic geoeconomics places Indonesia as an archipelagic country and a country maritime and is domiciled as a center of gravity and the global supply chain system. This situation causes Indonesia to experiencing threats and disturbances that implications for the country's maritime security. Government as state administrator has tried to overcome this by making product of the country's maritime security law. There are many regulations produced which applies at sea, but until now the regulations it is still sectoral in nature so that it arises disharmony and overlapping regulations and authority in maritime security. This also applies to law enforcement systems and state sovereignty in the affected sea by the laws and regulations.

To synergize the laws and regulations and related authorities with maritime security and enforcement law at sea, legislator have approved the wrong Marine Law one material charge regulates about security, safety, and law enforcement in the sea and formed Bakamla. Existence This Bakamla needs to be reviewed so that it doesn't there is an overlap of authority with Indonesian Navy which is domiciled as a component main defense of the country and served in the enforcement of sovereignty and law enforcement in Indonesian waters and jurisdictions Indonesia. The law enforcement system along with the mechanism must be accommodated clear and unequivocal in the laws and regulations, so as to create order and 
order in law enforcement at sea and provide guarantees of protection, certainty law, maritime security for Indonesia as a maritime country. This will affect realization of development and development Indonesian sea so that there is no disparity, can grow the economy, and improve the welfare of society. Law enforcement and sovereignty at sea also influenced by the determination of sea boundaries with neighboring countries. When it's achieved Then your goals and dreams will come true Indonesian nation as implied in the Preamble to the 1945 Constitution.

\subsection{Suggestion}

On the basis of that conclusion, security maritime from the aspect of regulation and enforcement the law needs to be harmonized with the system laws and regulations, make Indonesia's grand maritime, do assessment to conduct Bakamla, and immediately resolve and determine national boundaries on land, sea and air. Moreover, based on the law applicable international and national laws, the state must appoint the TNI AL which is the most responsible for maritime security and function as a leading sector without having to form a new institution.

\section{References}

[1] Dar, Syamsumar. Politik Kelautan. Jakarta: Bumi Aksara, 2010.

[2] Dirhamsyah. Penegakan Hukum Laut di Indonesia. Jurnal Oseana, Vol. XXXII. No. 1/Tahun 2007.

[3] Hadiwijoyo, Suryo Sakti. Batas-batas Wilayah Negara Indonesia, Dimensi, Permasalahan, dan Strategi Penanganan (Sebuah Tinjauan Empiris dan Yuridis). Yogyakarta: Penerbit Gava Media, 2009.

[4] Indonesia. Undang-Undang tentang Pelayaran. UU No. 17, LN No. 64 tahun 2008. TLN. No. 4849. Indonesia. Undang-Undang tentang Wilayah Negara. UU No. 43, LN No. 177 tahun 2008. TLN. No. 4925.

[5] Indonesia. Undang-Undang tentang Kepariwisataan. UU No. 10, LN No. 11 Tahun 2009. TLN. No. 4966. Indonesia. Undang-Undang tentang Perlindungan dan Pengelolaan Lingkungan Hidup. UU No. 32, LN No. 139 tahun 2009. TLN No. 5058.

[6] Kartika, S. D. (2016). Keamanan Maritim Dari Aspek Regulasi Dan Penegakan Hukum (Maritime Security From The Aspects Of Regulation And Law Enforcement). Negara Hukum: Membangun Hukum untuk Keadilan dan Kesejahteraan, 5(2), 143-167.

[7] Kementerian Perencanaan Pembangunan Nasional/Bappenas. Rancangan Teknokratik RPJMN 2015-2019. Jakarta, 2014.

[8] Usadi, B. (2014). Sistem Penegakan Hukum dalam RUU Kelautan. Jurnal Maritim (jurnalmaritim. com),(8 September 2014).

[9] Paonganan, Y., R.M. Zulkipli, dan Kirana Agustina. 9 Perspektif Menuju Masa Depan Maritim Indonesia. Jakarta: Yayasan Institut Maritim Indonesia, 2012.

[10] Sitompul, W. N., \& Setyawati, A. (2010). Kajian Kebutuhan Diklat Penyamaan Pemahaman Penegakan Hukum Keselamatan dan Keamanan di Laut dan Lingkungan Maritim. Jurnal Penelitian Tranpostasi Laut, 12(2), 98-116.

[11] Sodik, Dikdik Mohamad. Hukum Laut Internasional dan Pengaturannya di Indonesia. Bandung: PT. Refika Aditama, 2011. 